\title{
Association for Politics and the Life Sciences
}

\section{Executive Director}

Gary R. Johnson

Department of Political Science

Lake Superior State University

Sault Ste. Marie, MI 49783-1699

USA

Council

Samuel M. Hines (Chair)

College of Charleston (USA)

Andrea L. Bonnicksen (Vice-Chair)

Northern Illinois University (USA)

Ira H. Carmen (Secretary)

University of Illinois (USA)

Larry Arnhart

Northern Illinois University (USA)
Robert H. Blank

University of Canterbury (New Zealand)

Peter Corning

Institute for the Study of Complex Systems (USA)

Vincent Falger

University of Utrecht (The Netherlands)

Bruce Jennings

The Hastings Center (USA)

Joseph Losco

Ball State University (USA)

Roger D. Masters

Dartmouth College (USA)

Janna C. Merrick

University of South Florida (USA)

Steven A. Peterson

Penn State University, Harrisburg (USA)

For more information about PLS, contact Gary R. Johnson, Editor, Politics and the Life Sciences, Lake Superior State University, Sault Ste. Marie, MI 49783-1699, USA; telephone +1-906-635-2757; fax +1-906635-6693; e-mail GJOHNSON@GW.LSSU.EDU. 


\section{POLITICS $_{\text {And the }}$ LIFE SCIENCES}

\section{Manuscript Submission \& Review}

The editor welcomes high quality manuscripts from scholars and scientists in any discipline, and on a wide variety of topics that relate to politics and the life sciences, including:

- a broad range of policy subjects, from biomedical policy to biological warfare, from biotechnology to environmental policy;

- a broad range of biobehavioral subjects, both empirical and theoretical.

If a manuscript's subject or approach involves both politics and any of the life sciences, submission to $P L S$ is appropriate. Since politics is not necessarily restricted to humans, manuscripts on nonhuman species are also welcome.

Submitted manuscripts are sent to outside referees who are established scholars in relevant fields. Some of the accepted manuscripts are reviewed by peer commentators, and their reactions published together with a response from the article's author(s). Readers' comments are also invited and published selectively in subsequent issues as continuing commentary.

Authors should submit five copies of a manuscript to be considered for publication, typed double-spaced (including a 100-150 word abstract, quotations, notes, and references). A manuscript may be submitted for review using any common format for notes, citations, and references. The final version of an accepted manuscript, however, must follow the journal's style requirements (based on the Chicago Manual of Style), and must be submitted on diskette. Manuscripts currently under consideration by other journals should not be submitted.

Authors of articles, commentaries, updates, and similar items will receive 25 free copies of their article (or 50, if they can use them). In addition, some or all of these offprints can be mailed free of charge to people designated by the author.

All article manuscripts, commentaries, bibliographic information, and news items should be submitted to Gary R. Johnson, Editor, Politics and the Life Sciences, Lake Superior State University, 650 West Easterday Ave., Sault Ste. Marie, Michigan 49783-1699, USA (telephone +1-906-635-2757; fax +1 -906-635-6693; E-mail: GJOHNSON@LAKERS.LSSU.EDU)

\section{Book Reviews}

Inquiries regarding book reviews on public policy topics should be directed to Andrea L. Bonnicksen, Department of Political Science, Northern Illinois University, DeKalb, IL 60115-2887, USA (telephone +1-815-753-7040; E-mail ALBCORN@NIU.EDU).

Inquiries regarding book reviews on biobehavioral topics should be directed to Joseph Losco, Department of Political Science, Ball State University, Muncie, IN 47306-0515, USA (telephone +1-765-285-8982; E-mail 00JALOSCO@BSUVC.BSU.EDU).

\section{Subscription Information}

Politics and the Life Sciences is the journal of the Association for Politics and the Life Sciences (APLS). It is published every March and September. Information on editorial advisory board, and where PLS is indexed, is on the inside front cover. ISSN 0730-9384.

Membership in the association includes subscriptions to the journal and newsletter (APLS News), the APLS Directory, and other mailings about the activities of the association. Contact Gary R. Johnson, Executive Director, Association for Politics and the Life Sciences, Lake Superior State University, 650 West Easterday Ave., Sault Ste. Marie, MI 49783-1699, USA (telephone +1-906635-2757; E-mail APLS@,LAKERS.LSSU.EDU). Pay by check (payable to the Association for Politics and the Life Sciences), Mastercard, Visa or EuroCard.

Individual membership for one year, effective in 2000:

US $\$ 55$ or $£ 33$

Individual membership for two years, effective in 2000:

US $\$ 105$ or $£ 63$

Individual membership for three years, effective in 2000:

US\$155 or $£ 93$

Student membership for one year, effective in 2000:

US\$35 or $£ 21$

\section{Institutional Subscriptions}

All other enquiries on subscriptions and back issues of Politics and the Life Sciences to PLS, Beech Tree Publishing, 10 Watford Close, Guildford, Surrey GU1 2EP, England (telephone +44 1483 824871; fax +44 1483 567497; E-mail PAGE@,SCIPOL.DEMON.CO.UK). Pay either:

by check in US $\$$ or $£$ payable to Beech Tree Publishing; other negotiable currencies: use prevailing exchange rates and add $£ 5 /$ US\$9 per cheque;

or with Visa, MasterCard, Eurocard, or Access card (give card number, expiry date, address used for billing you);

or with bank transfer (in $£$ only) to Beech Tree, account 9655476 , National Westminster Bank, 1 Princess St (60-00-01), London;

or with Unesco coupons; or ask to be invoiced.

Institutions: US\$90 or $£ 51$

Third World/East Europe: US\$76 or $£ 44$

\section{Web Sites}

Association: HTTP://WWW.LSSU.EDU/APLS

Journal: HTTP://WWW.LSSU.EDU/APLS/PLS

Copyright Although individual items in this journal say (C) Beech Tree, this phrasing is only for administrative convenience; the real copyright owner is The Association for Politics and the Life Sciences, on whose behalf Beech Tree administers copyright matters relating to this journal.

Those wishing to make photocopies of items in this journal may do so only if they conform to the rules of their national copyright licensing scheme, if there be one (such as the Copyright Clearance Center in the USA; fees are given in the codes at the foot of the first page of each item); or if they obtain permission from Beech Tree Publishing. No other copying, electronic storage or form of reproduction of all or any of the contents of this journal is permitted without the publisher's permission, except for the covers and contents page. 


\section{POLITICS AND the LIFE SCIENCES}

\section{Main Articles in This Issue}

\section{Male Age Composition and} Severity of Conflicts

Christian G. Mesquida and Neil I. Wiener (York University, Canada) Pages 181-189
The Kankakee Wetlands: A Case Study in Ethics and Public Policy Sarah E. Roberts (Purdue University, USA)

Pages 191-200
From a behavioral ecology perspective, all forms of warfare are instances of collective aggression perpetrated predominantly by coalitions of young men. Such coalitions are manifestations of cross-cultural sex differences in aggressive behavior and may be conceptualized as a form of intrasexual competition, occasionally to obtain mates, but more often to acquire resources for the attraction and retention of mates. All societies have young males, yet wars are discrete events that can take place even after long periods of peace. Therefore, an additional factor is needed to explain the episodic nature of the phenomenon. We have proposed (Mesquida and Wiener, 1996) that the most reliable factor in explaining episodes of coalitional aggression is the relative abundance of young males. In this article, we present additional evidence to that effect. The ratio of the number of men ages 15 to 29 years of age versus men 30 and older in a population appears to be associated with the occurrence and severity of conflicts as measured by the number of war casualties. A series of analyses of demographic and war casualty data indicates that the relative prevalence of young men consistently accounts for more than one third of the variance in severity of conflicts.

In 1996, the U.S. Fish and Wildlife Service made a proposal to restore and preserve 30,000 acres of wetlands in Indiana's Kankakee River basin. Local farmers opposed this, expressing concerns about how a wildlife refuge would affect farming communities along the Kankakee River. Undergirding what seems to be a simple conflict between incompatible environmental and economic interests is a more fundamental conflict between competing ethical frameworks for evaluating public policy. One helpful approach is to examine the normative issues in the Kankakee dispute in terms of the contrast between consequentialist and non-consequentialist ethical frameworks. This article attempts to establish that a failure to recognize alternatives to the consequentialist framework has resulted in a failure of opposing parties to recognize and address each other's ethical concerns. An analysis of the Kankakee wetlands dispute will reveal why it is important for environmentalists to be cognizant of alternatives to consequentialist ethical frameworks. 